\title{
TEMÍSTOCLES: APOGEU E OSTRACISMO. AS DUAS FACES DA MESMA MOEDA
}

\section{THEMISTOCLES: APOGEE AND OSTRACISM. THE TWO SIDES OF THE SAME COIN}

Filipe Paiva Cardoso ${ }^{1}$

Resumo: O ostracismo de Temístocles, um dos responsáveis pelo crescimento da democracia ateniense, ocorreu num período crítico para a Grécia, acabada de sair das guerras Medo-Persas e em pleno conflito entre defensores de sistemas oligárquicos e democráticos. A tese neste artigo é a de que a expulsão do estadista visou abrir caminho para o aristocrata Címon tomar o poder em Atenas, tal e qual como ocorreu com o próprio Temístocles, cuja ascensão ao poder foi facilitada pelos ostracismos da década de 480 a.C. "Quem vive pela espada, morre pela espada." Neste ostracismo em muito ajudou a intervenção de Esparta, já que Temístocles sempre teve como prioridade impedir os Lacedemónios de ter uma posição dominante sobre toda a Grécia. Tal posição acabou por incendiar os espartanos, que viam em Címon um aliado, levando-os a lançar uma campanha de descrédito contra o estadista que veio ajudar a convencer os atenienses a expulsá-lo.

Palavras-chave: Grécia Antiga; Temístocles; Ostracismo; Guerras Medo-Persas; Atenas; Esparta.

Abstract: The ostracism of Themistocles, one of the major contributors for the growth of Athenian democracy, happened in a critical period for Greece, soon after the end of the Medo-Persian wars and when Athens was immersed in a conflict between supporters of oligarchic and democratic political systems. The thesis in the article points that Themistocles' ostracism was a way of opening Athens leadership to Cimon, an aristocrat, just like it happened with Themistocles himself, when his

${ }^{1}$ Graduando do $5^{\circ}$ Semestre da licenciatura em História pela Faculdade de Letras da Universidade de Lisboa. E-mail: paiva.cardoso@gmail.com. Artigo orientado pelo Professor Rodrigo Furtado. 
path to power was facilitated by a number of ostracisms that occurred in the 480's b.C. "Live by the sword, die by the sword." Sparta played a huge role in Themistocles' ostracism, because the statesman had as a priority to prevent the Lacedemonians from becoming hegemonic in Greece. This attitude made the Spartans launch a defamatory campaign against Themistocles which helped convince the Athenians to vote for his ostracism.

Keywords: Ancient Greece; Themistocles; Ostracism; Medo-Persian wars; Athens; Sparta.

\section{Trajecto, perfil e ideologia}

Filho de mãe não-ateniense ainda que oriundo de uma família conceituada, o trajecto singular que Temístocles viria a conseguir em Atenas em pouco ficou a dever aos seus antepassados, devendo mais à sua ambição, vontade de estar no centro das decisões, capacidade de antecipação e invulgares dotes para a oratória, características que desde criança o levaram a trilhar um caminho que o guiaria aos patamares mais elevados da política Ateniense. Ainda criança, e nos intervalos entre aulas, enquanto os seus colegas se dedicavam a jogos e brincadeiras, já Temístocles se dedicava a grandes discursos, normalmente em defesa ou acusação de um colega (PLUTARCO, TEMÍSTOCLES, 2.1). “Ai criança! Tu não serás jamais coisa pequena, algum dia serás um grande bem ou um grande mal", vaticinava-lhe já o seu educador segundo Plutarco (TEM., 2.2), historiador que assim nos abre a porta para o carácter ambíguo deste defensor da Democracia através de meios pouco ortodoxos que viveu entre 524 e 459 a. C..

"Em ambição superava todos os homens." Para Plutarco (TEM. 5.2), não é de estranhar que rapidamente Temístocles se tenha afeiçoado 
pela política, caminho evidente para uma alma tomada pelo anseio de glória e para quem os fins justificavam os meios. Esta seria, de resto, a razão pela qual Temístocles nunca terá merecido a confiança de $100 \%$ dos atenienses, ainda que muitas vezes o tenham apoiado. De facto, atraiu rapidamente a inimizade entre os mais poderosos, seus inimigos naturais, já que eram eles que ocupavam os cargos mais desejados por este jovem ambicioso cuja carreira em muito assentava no ataque à aristocracia e na elevação do homem comum. Entre as maiores inimizades que veio a recolher encontra-se Aristides, homem oposto a Temístocles e que Heródoto (LIVRO VIII, 79) descreve como o mais merecedor e mais justo entre todos os Atenienses, um aristocrata que olhava para a governação como um meio para levar a cabo as políticas mais importantes e não como forma de obter glória, enquanto se defende o Estado. A diferença determinante entre estes dois estadistas, porém, residia sempre de acordo com Plutarco (ARISTIDES, 2.1), precisamente nas formas opostas de governo que defendiam para Atenas: "Ele [Aristides] portanto favorecia um governo aristocrático, e sempre se opôs a ele, o campeão do povo, Temístocles, filho de Neocles."

Além do desejo e sede de glória e de reconhecimento, assim como o recurso a metódos pouco ortodoxos para conseguir responder a todos estes desejos, Temístocles notabilizou-se pela sua visão estratégica, antecipando e mesmo provocando por várias vezes eventos determinantes para o futuro de Atenas e da Grécia num período altamente conturbado. Ainda em 490 a. C., no meio da euforia generalizada na polis com a vitória de Milcíades sobre os persas na 
batalha da Maratona, e já depois de ter ocupado o cargo de Arconte Epónimo, em 493/2 a. C., Temístocles então com apenas 34 anos adivinhava já vingança futura do império derrotado. "Enquanto os demais olhavam para a batalha como o fim da guerra, aos olhos de Temístocles não era se não o início de combates maiores para os quais ele já estava em preparação para salvar a Grécia”, diz Plutarco (TEM., 3.4) numa descrição do talento inato para a antecipação de Temístocles, talento que, contudo, poderá ter beneficiado pelo menos numa ocasião determinante da apropriação de argumentos de terceiros, como veremos adiante.

A visão e antecipação de Temístocles face às necessidades de Atenas já se fazia sentir antes da batalha de Maratona: basta ver que durante o seu arcontado deu início à fortificação do porto ateniense do Pireu, para que este servisse de base naval mais resguardada, e já antes tinha sido um dos grandes defensores do apoio de Atenas à revolta das poleis da Jónia contra o domínio Persa, mesmo depois de Atenas deixar a Jónia entregue a si mesma, ainda em 498 a. C., oferecendo de bandeja o domínio do Egeu aos Persas. Para Temístocles, este mar era vital para as aspirações de Atenas, que o estadista sempre defendeu que devia viver de frente para o Egeu e não de costas. Isto porque, explicam José Ribeiro Ferreira e Delfim Leão (2010), nesta altura quem dominasse o Egeu e o tornasse seguro de ataques piratas iria beneficiar de vários proveitos económicos e de um acrescido peso militar e diplomático. Temístocles defendia também a aposta naval porque se o poder de Atenas assentasse numa indisputável frota tal daria mais importância 
aos remadores das trirremes, normalmente os cidadãos da quarta classe censitária de Sólon, os tetas, reduzindo assim a força das classes mais elevadas, detalham os mesmos autores. Foi aliás graças a si que a polis conseguiu inverter "as políticas dos antigos Reis Atenienses" de viver para a agricultura e não para a navegação, inversão que permitiu "aumentar os privilégios dos homens comuns contra os nobres, enchendo-os de coragem, já que o poder estava agora na mão de capitães, contramestres e pilotos" (PLUT. TEM. 19.4). Esta inversão na lógica do poder, naturalmente, não lhe trouxe grandes amizades entre as famílias aristocratas de Atenas.

Terá sido Temístocles (FERREIRA, LEÃO, 2010)² que durante o seu arcontado encomendou a Frínico, um dos dramaturgos atenienses, que escrevesse "A Tragédia de Mileto", onde era descrita em pormenor a sorte desta polis Jónia às mãos dos Persas (massacre de boa parte dos homens, redução à escravatura das mulheres e crianças e deportação do resto da população para a costa do Golfo Pérsico). A tragédia visava recolocar o apoio de Atenas aos Jónios na ordem do dia, mas impressionou de tal forma nas Dionísias daquele ano que Frínico acabou multado e a obra não mais pode ser apresentada. Os Atenienses eram especialmente sensíveis ao destino de Mileto, já que segundo os seus mitos teria sido fundada pelo filho do último rei de Atenas, Codrus (HERÓDOTO, IX, 97).

A vitória em Maratona, atribuída a Milcíades, membro de uma das mais poderosas famílias Atenienses, trouxe o auge e logo a queda

${ }^{2}$ P. 151. 
em desgraça deste estadista. De facto, depois desta vitória histórica sobre os Persas, Milcíades pediu aos cidadãos autorização e financiamento para atacar com 70 navios uma região, sem nomear qual, prometendo fazer de Atenas uma cidade ainda mais rica. Com a fama e a vitória de Maratona por trás, os Atenienses aceitaram a proposta. Milcíades decidiu então atacar a ilha de Paros, que teria apoiado os Persas na batalha de Maratona, mas Hérodoto (VI, 133) atribui também razões pessoais para este ataque. Independentemente das razões, certo é que a expedição foi um fracasso retumbante, com a frota de Milcíades a voltar a Atenas derrotada e o próprio ferido de morte. Foi a queda em desgraça do herói de Maratona, acusado de enganar a Assembleia, que chegou a discutir a sua condenação à morte. Acabou condenado a pagar 50 talentos, dívida que com a sua morte recaiu sobre o seu filho, Címon, outro aristocrata que viria a influenciar de forma determinante a vida de Temístocles e de Atenas.

A queda em desgraça de Milcíades em 489 a .C. marcou o início de uma conturbada era política em Atenas, ou pelo menos a sua transformação de Guerra Fria em Guerra Quente, por assim dizer, com a sucessão de vários ostracismos ${ }^{3}$ que vão afastando políticos infuentes de cena, exilados, pois não seriam raros os Atenienses que defendiam uma política de entendimento com os Persas, ao invés da resistência (CAMBRIDGE ANCIENT HISTORY, VOL. IV) ${ }^{4}$. Aliás, Xantipo, principal acusador de Milcíades, casado com a sobrinha de Clístenes e

${ }^{3}$ Em 488/7, Hiparco (Pisistrátida); em 487/6, Mégacles (Alcmeónida); em 484/5, Xantipo (Alcmeónida); em 483/2, Aristides.

${ }^{4}$ Págs. 341-342. 
pai de Péricles, poderá ter precipitado a queda de Milcíades em resposta ao desejo dos Alcmeónidas (família a que estava ligado por casamento) de um entendimento com os Persas. Esta suspeita que grassava em Atenas é relatada por Heródoto (VI, 115-124) que, contudo, se recusa a acreditar nos boatos.

A crescente certeza de novo ataque Persa, assim como a explosão de uma guerra ideológica em Atenas entre os que defendiam o entendimento com os Persas e aqueles que repudiavam qualquer negociação com os mesmos, assim como, já posteriormente a esta discussão, as fortes discordâncias existentes ao nível da estratégia a seguir na defesa contra a invasão de Xerxes, acabou por trazer para a ordem do dia durante a década de 480 a lei do ostracismo que, assim, só duas décadas depois da sua criação começou a ser efectivamente usada.

\section{O Ostracismo}

Para entender todo o enquadramento do ostracismo de Temístocles, assim como os anos conturbados vividos na década de 480 e seguintes em Atenas, é primeiro necessário ter presente o que era e o que visava a lei do ostracismo. Segundo Aristóteles (CONSTITUIÇÃO DOS ATENIENSES, 22), esta lei foi criada por Clístenes no meio das profundas reformas ao sistema político então a serem forjadas na Polis. O ostracismo terá nascido no final do século VI, na época de Clístenes, mas só dois anos depois da vitória ateniense em Maratona e "depois da população ter ganho auto-confiança, pela primeira vez usaram a lei do ostracismo". 
Entre as razões que levaram Clístenes a criar o ostracismo estaria o receio de Atenas voltar a cair num regime tirano como o imposto por Pisístrato, "que tirou vantagem da sua posição como líder popular e general para nomear-se tirano". A primeira vítima do ostracismo, em 488, foi precisamente Hiparco, filho de Carmo, personagem bem próxima de Písistrato, e arconte em 496/5. A actuação de Hiparco antes, durante e depois do seu arcontado, mas também quando da batalha de Maratona, terá dado indícios de que poderia estar em causa uma futura restauração do tirano Hípias, filho de Písistrato.

O ostracismo era sobretudo uma lei preventiva, pelo menos na teoria. Explica Aristóteles (POLÍTICA, 3.13) que a "igualdade é o objectivo último dos estados democráticos”, razão pela qual foi criado o ostracismo, para que "fossem ostracizados e banidos da cidade por um período de tempo aqueles que, por razões da sua riqueza, número de amigos ou qualquer outro tipo de influência política, prevalecessem demasiado". Apesar da explicação teórica, Aristóteles é também o primeiro a reconhecer os riscos desta lei: "Este princípio, contudo, não tem sido aplicado justamente nos Estados pois, ao invés de procurarem o bem para a sua Constituição, o ostracismo tem sido usado para beneficiar algumas facções.” Além do uso desta lei por algumas facções para seu próprio privilégio, afastando rivais políticos do caminho, também a própria ideia de democracia radical levou a que o ostracismo se transformasse numa consequência natural de simples derrotas eleitorais. "Em breve homens passaram a ser ostracizados porque se opunham às políticas apoiadas pela maioria do eleitorado" 
(RAUBITSCHEK, 1951), algo de que encontramos prova, por exemplo, na já citada dura rivalidade entre Temistócles e Aristides, duas das mais fortes personalidades do início do séc. $\mathrm{V}$ ateniense.

O conflito entre estes adversários políticos, sobretudo durante a segunda metade da década de 480, chegou ao ponto de Aristides sentirse obrigado a propor as suas medidas através de outros Atenienses já que somente assim conseguia evitar a oposição quase automática de Temistócles, que se opunha a qualquer uma das suas iniciativas (PLUT., ARIST. 3.3). De acordo com Plutarco (PLUT., ARIST. 3.1-3), Aristides, que via Temístocles como "um agitador inconsciente", chegou mesmo ao limite quando, depois de infligir uma derrota política a Temistócles, declarou à saída da Ecclesia que "o estado de Atenas não será seguro enquanto Temistócles e ele próprio não fossem empurrados para um confronto". Em síntese, e pelo sistema ateniense que acabou por estar em vigor, apenas o ostracismo poderia decidir em tempo útil qual de duas políticas opostas seria seguida.

Plutarco (ARIST. 7.2-6) também encontra várias falhas no ostracismo, "falaciosamente referido como uma forma forçada de promover a humildade e de conter níveis opressivos de prestígio, era na realidade um exorcismo misericordioso do espírito dos invejosos, que resultava numa vontade de punir, não de uma forma irreparável, mas com uma mudança de residência durante dez anos". E dá como exemplo o ostracismo de Aristides, quando um cidadão anónimo pediu ao próprio, sem o reconhecer, que escrevesse o seu nome para o votar ao ostracismo. Aristides terá perguntado a este cidadão se tinha sido de 
alguma forma prejudicado por quem estava a condenar, ao que recebeu como resposta: "Não, nem o conheço. Mas estou cansado que o chamem 'O Justo' por todos os lados." Mais tarde, de acordo sempre com Plutarco, também Temístocles iria sentir na pele o peso que a injustiça e a inveja tinham nos ostracismos, pois também ele cansou os Atenienses de tanto vangloriar os seus feitos, facilitando a vida aos seus rivais e inimigos.

O método em que decorria um ostracismo previa que as propostas fossem discutidas durante a Assembleia da sexta pritânia. Se a intenção de votar ostracismos fosse aprovada, então o processo em si decorreria na Ágora, durante a oitava pritânia e sob supervisão dos arcontes. Para que um ostracismo fosse válido era preciso um mínimo de seis mil votos, inscritos num ostrakon, espécie de barra de cerâmica, e uma maioria simples ditava o resultado. Explica Plutarco (ARIST. 7.4-5): "Cada cidadão pegava num ostrakon, escrevia o nome do cidadão que queria retirar da cidade e levava o seu voto para um local na ágora rodeado por cercas. Os arcontes primeiro contavam o total de votos. Se fossem menos de seis mil o ostracismo era nulo. Depois separavam os nomes e proclamavam o exílio por dez anos do homem que tivesse recebido mais votos, que mantinha os direitos sobre os seus rendimentos e propriedades.” Já Diodoro (LIVRO XI, 55.2) é mais directo, referindo que os Atenienses escreviam nos ostrakon o nome "do homem que julgavam ter mais poder para destruir a democracia", votando-o ao ostracismo, forma que tinham "não para castigar qualquer crime, mas 
para baixar a presunção de homens que subiram demasiado, através do exílio".

Os Atenienses com o tempo perceberam que o ostracismo se transformou mais numa forma de punição orientada por ódios e invejas do que de prevenir a ascensão de tiranos (PLUT., ARIST., 7.2-4). Foi por volta de 417 a. C. que se registou o último dos ostracismos, quando Hipérbolo, cidadão das classes mais inferiores, e alvo dos poetas cómicos que o elegiam como comparação quando queriam denegrir alguém, se transformou numa das vítimas desta lei ${ }^{5}$.

\section{A ascensão de Címon e o ostracismo de Temístocles.}

O eventual regresso dos Persas à Grécia tinha-se tornado então na década de 480 a. C. no principal tema político em Atenas, com muitos a temerem que a vitória em Maratona tivesse resultado da sorte e que os Persas seriam imparáveis caso avançassem com reais intenções de conquista - isto porque a primeira guerra Persa visou sobretudo a vingança sobre os aliados da Jónia, e não a conquista da Grécia. A escolha entre a guerra e uma política de apaziguamento com os Persas, que em troca da soberania poupassem Atenas a um massacre, eram visões em oposição.

5 “Alcíbiades e Nícias eram os mais poderosos do Estado e estavam em conflito. Quando a população estava prestes a exercer o ostracismo (...), ambos chegaram a um acordo, uniram as facções, e votaram Hipérbolo ao ostracismo. A população irritou-se com esta atitude, considerando-a um insulto e um abuso à instituição, acabando por abandonar" os ostracismos, conta Plutarco, na Vida de Aristides (7.3). 
Um dos grandes defensores da resistência total aos Persas é Temístocles a quem, apesar de não surgir directamente associado à grande vaga de ostracismos na década de 480, muitos atribuem responsabilidades na mesma. De facto, ao longo deste período terão sido contados 2264 votos a pedir o ostracismo de Temístocles, prova de que vários aristocratas tentaram condená-lo ao exílio durante os anos das grandes purgas atenienses, seja em reacção à sua participação nos ostracismos de outros aristocratas, seja em reacção às suas políticas prodemocracia. Mas Temístocles, "que tratava todos os cidadãos pelo nome, guardando-os na memória, e mostrando-se sempre um juíz inflexível" (PLUT. TEM. 5.4), estando assim nas boas graças da plebe por esta altura, sobreviveu aos ataques. Sorte oposta teve Xantipo em 484/5 e, depois, já com maior quota de responsabilidade de Temístocles, seguiu-se a condenação de Aristides, em 483/2, num exílio que já não visava decidir entre a resistência ou a rendição, mas sim sobre qual a melhor forma de combater os Persas, como já explicámos.

A condenação ao exílio nesta época de vários políticos influentes em Atenas através dos ostracismos atrás referidos, que visaram de Pisistrátidas a Alcmeónidas, acaba por deixar o caminho livre a Temístocles para finalmente avançar com a sua política de rearmamento e de uma aposta definitiva no poder naval como o futuro de Atenas (CAMB. ANC. HIST, IV $)^{6}$. Habituados que estavam os cidadãos a verem distribuídos por si os lucros obtidos com as minas de prata, Temístocles aproveitou a descoberta das minas de Maroneia em 483/2

${ }^{6}$ P. 342. 
para quebrar este hábito, pedindo à Assembleia para empregar os rendimentos na construção de 100 barcos de guerra, argumentando então com a ameaça de Egina, embora sem esquecer os Persas. "Atreveu-se a propor ao povo que abdicasse daquele rendimento para que se construíssem galeras para a guerra contra os eginetas", conta Plutarco (TEM. 4.2). "Construíram-se assim, com aquele dinheiro, cem galeras que acabaram por combater Xerxes em Salamina.”

A criação de uma armada forte foi também a forma que Temístocles encontrou para enfraquecer as classes mais altas de Atenas, já que até então, e a cada batalha vencida por generais de certas famílias, novos rumores surgiam sobre o eventual aproveitamento da fama para fazer regressar a tirania à Polis. Com a marinha consegue darse um papel de relevo aos cidadãos mais carenciados, vedados de grandes papéis militares por falta de meios. Quando esses cidadãos se tornam ferramenta essencial nas vitórias dos Atenieneses ${ }^{7}$ acabam por

\footnotetext{
${ }^{7}$ Algo que ficou evidente depois da vitória frente aos Persas. "O acontecimento mais decisivo na luta pela liberdade - a Batalha de Salamina - viera confirmar que o futuro de Atenas estava na força naval. No entanto, é importante registar que os marinheiros vencedores do Artemísio, Salamina e de Mícale diferiam social e economicamente dos hoplitas e dos cavaleiros. Estes últimos estavam ligados à terra e tinham a obrigação de custearem os próprios equipamentos e montadas. Os marinheiros, pelo contrário, eram assalariados da pólis e não possuíam outro meio de subsistência que não fosse o soldo recebido pela função na frota. Desse modo, os cidadãos mais pobres de Atenas, que haviam sido peças indissociáveis da eficácia da frota, saíram dessas vitórias muito prestigiados e quase granjeados ao estatuto de heróis. Por conseguinte, as Guerras Medo-persas (...) ajudaram a cimentar o regime democrático em Atenas e criaram ainda as condições para um aperfeiçoamento da soberania popular", in, Ribeiro Ferreira, José e Ferreira Leão, Delfim, pp. 168 e 169.
} 
ajudar a cimentar o regime democrático da polis, cujos louros das vitórias passam a recair menos nas aristocracias e mais nos cidadãos.

Apesar de todas as purgas levadas a cabo durante a década de 480 a. C., e com o advento da invasão persa, todos os cidadãos Atenienses que tinham sido condenados ao ostracismo acabam por ser autorizados a regressar em 480/1 à polis (ARIST. CONST. 22.8)

São vários os estratagemas a que Temístocles recorre durante a guerra para assegurar por qualquer meio que esta corra de feição aos Atenienses, sendo que segundo Plutarco (TEM. 6.3, 5.6) os maiores de todos os seus feitos foi "ter dissipado as guerras entre os Gregos, reconciliando as cidades entre si, persuadindo-as a renunciar às suas inimizades" em nome do inimigo comum, os Persas, assim como ter conseguido a suspensão dos ostracismos do passado, algo que the permitiu chamar de volta Aristides, que os Atenienses temiam que fosse apoiar os bárbaros.

De acordo com Plutarco (TEM., 10, 1-4) e também Heródoto (VII.143), já durante a guerra, e tanto através de falsos prenúncios dos Deuses, com os quais conseguiu convencer os Atenienses a abandonarem Atenas evitando o massacre destes, ou através de subornos recebidos e pagos (HER., VIII, 4-5), bem como através de recados enviados ao rei persa oferecendo-se como traidor para induzir Xerxes em erro (PLUT., TEM., 12.4), Temístocles manipulou quase todos os episódios determinantes da guerra para que esta terminasse de forma favorável para os Gregos. 
A insistência em ficar em Salamina, episódio apontado como um dos seus maiores triunfos e como um exemplo da sua capacidade de antecipação e de estratega, pode, no entanto, estar sobreavaliado na biografia de Temístocles. Segundo Heródoto (VIII.57-58), historiador da época que relatamos, foi Mnesifilio, amigo e perceptor de Temístocles, que, quando soube da intenção de abandonar Salamina, convenceu o estadista da importância de não recuar e de combater naquele estreito, argumentos que Temístocles posteriormente apresentou como seus a Euribíades, almirante espartano encarregue do comando da frota pan-helénica, para o convencer a ficar em Salamina. Plutarco refutou na sua época esta teoria e Frank Frost (FROST, 1971) atribui a mesma aos preconceitos existentes no século $\mathrm{V}$ contra Temístocles, que terão levado as fontes de Heródoto a alterar os pressupostos da história de forma a desvalorizar o papel de Temístocles. Sobre isto cabe-nos um comentário, lembrando que se a proximidade temporal de Heródoto a Temístocles pode ser vista como uma vantagem para os seus relatos face aos de Plutarco, por outro lado ela acarreta um risco, pois essa proximidade face a um evento não é normalmente boa conselheira para o discernimento histórico. É também de salientar que existiu de facto uma tendência de desvalorização do papel de Temístocles na guerra contra os Persas.

Com o fim da guerra contra os Persas, o que poderia ser um período áureo da vida de Te

místocles rapidamente se deteriora. Na recolha dos louros por esta grande vitória, e entre as cidades, coube a Egina e depois a Atenas, o 
maior dos reconhecimentos pela coragem demonstrada na guerra, mas entre os homens "todos atribuíram o primeiro lugar a Temístocles, ainda que a inveja que sentiam tenha impedido de o fazerem directamente". Ou seja, quando todos os generais se reuniram para deliberar sobre prémios de valentia, todos se declararam como os melhores, dando todos eles o segundo lugar a Temístocles (a tal tendência de desvalorizar o seu papel que referimos há pouco), explica Plutarco (TEM, 17.1). Esparta aqui aproveitou o carácter e a ambição de Temístocles para virar os Atenienses contra si.

Depois de os Espartanos perceberam que a vitória em Salamina mostrava que os Atenienses estavam prontos para disputar a liderança da Grécia com os Lacedemónios, rapidamente se esforçaram para conter o orgulho destes, primeiro dando primazia a Egina no reconhecimento do esforço de guerra, relegando o esforço ateniense para segundo plano. Ao mesmo tempo, avançaram com uma série de oferendas a Temístocles, o dobro das reservadas para quem tinha ganho distinções. "Quando Temístocles aceitou as oferendas, os Atenienses removeramno de general entregando o cargo a Xantipo" (DIODORO, XI, 27.3). Muito bem recebido na polis dos Espartanos, assim como no Festival Olímpico que se seguiu à vitória sobre os Persas, o Ateniense não sentia por esta altura que os seus cidadãos lhe dessem o valor que merecia, ou achava que merecia. Sentia que os Atenienses o viam como uma árvore, "correndo para debaixo dos seus ramos quando há tempestade" (PLUT. TEM. 18.3), mas ignorando-o ou cortando-lhe os ramos nos tempos de bonança. 
Além dos problemas ou da falta de amor que sentia vinda dos seus cidadãos, Temístocles, assim como a Grécia no geral, voltava a pensar nas antigas quezílias entre as várias poleis gregas, adormecidas durante a guerra Persa. A política interna de Atenas volta a ser palco de tensões entre facções pro-Esparta e anti-Esparta. Temístocles, tendo mantido relações com todos os chefes Gregos durante as guerras e sabendo que a Lacedemónia era contra a reconstrução da muralha de Atenas, destruída pelos Persas, foi a Esparta manter aparentes negociações de paz que, contudo, visaram apenas levantar uma fachada e ganhar tempo para a sua polis terminar a reconstrução da dita muralha. A jogada foi de muito difícil digestão em Esparta.

O ódio dedicado por Esparta a Temístocles acabou por explodir realmente quando este conseguiu impedir os Espartanos de retirar da aliança dos estados Gregos todas as poleis que não tinham combatido directamente contra os Persas. O Ateniense opôs-se ao plano, demonstrando que tal decisão ia entregar o comando da aliança aos Espartanos, que assim poderiam colocá-la a funcionar inteiramente ao serviço das suas vontades. Os delegados da aliança acabaram por chumbar a proposta de Esparta e "foi por esta razão em particular que ele [Temístocles] se tornou insuportável para os Lacedemónios, que passaram a tentar impor Címon, filho de Milcíades e sucessor político de Aristides, tornando-o no rival político de Temístocles", conta Plutarco (TEM. 20.4). "Na realidade, opunha-se a Temístocles quando ele exaltava a Democracia excessivamente, como Aristides fez." (PLUT. CÍMON 10.7) 
Aqui precisamos de recorrer a Diodoro (IV, 54.2-5) para melhor entender a dimensão da campanha lançada por Esparta contra Temístocles. Os Lacedemónios, e como "Esparta estava reduzida a um estado humilde por causa da traição do seu general [Pausânias], enquanto Atenas estava com óptima reputação, porque não viu nenhum dos seus cidadãos condenado por traição", "estavam desejosos de envolver Atenas em acusações igualmente degradantes" e como "Temístocles era dono de óptima reputação entre os Atenienses, acusaram-no de traição, alegando que ele era grande amigo de Pausânias”. Mas além de o associarem a esta traição, que já abordaremos, os Espartanos "mantiveram conversações com os inimigos de Temístocles, incitando-os a apresentar acusações contra ele, oferecendo-lhes dinheiro". Esparta estava assim a intervir directamente na política interna de Atenas, procurando elevar naquela polis um político mais favorável às suas ambições, no caso Címon.

Além de Esparta, Temístocles tornou-se odiado igualmente pelos aliados gregos, já que terá viajado ao longo das ilhas gregas onde procurou extrair dinheiro a estas cidades. "Tornou-se odiado também pelos aliados, por navegar pelas ilhas a tentar extrair-lhes dinheiro." (PLUT. TEM. 21) Esta parte da história chega-nos também por Heródoto (VII, 111-2) mas, ao contrário do que ocorre com Mnesífilio em Salamina, não foi omitida por Plutarco. “Os Helénicos entretanto (...) estavam a investir em Andros para tomá-la: os Ândrios foram os primeiros das ilhas que, ao pedido de Temístocles por dinheiro, recusaram dá-lo (...). Estes, recusando pagar, foram cercados: e 
Temístocles não perdendo o desejo pelo ganho enviou mensagens ameaçadores às outras ilhas a pedir dinheiro (...) a dizer que se não lhe dessem o que era exigido, iria levar a frota dos helénicos, cercá-los e invadi-los. Assim angariou grandes quantias de dinheiro aos Carístios e aos Pários."

Já com bem mais de duas mãos cheias de inimigos angariados ao longo dos últimos anos, de políticos a cidadãos comuns, e com as notícias da tentativa de extorsão às poleis aliadas, não demorou muito até que alguns poetas gregos começassem a compor contra Temístocles, ("Por três talentos de prata navegou - até à perdição, perdoando alguns exilados injustamente, perseguindo outros, e matando alguns”), até porque um deles, Timócreon, autor do excerto citado, tinha sido condenado ao ostracismo com voto favorável do estadista Ateniense (PLUT. TEM. 21-4). Já antes, convém sublinhar, Temístocles tinha sido associado a subornos, no caso em plena guerra contra os Persas, pouco tempo antes da Batalha de Artemísio, antecessora da Batalha de Salamina. Diz-nos Heródoto que os Gregos também aqui quiseram recuar, deixando a Eubeia à sua sorte. Quando souberam disto, os Eubeus tentaram convencer Euríbiades, o general Espartano com o comando da armada, a atrasar a retirada uns dias para terem tempo de tirarem as crianças e os escravos para locais de segurança. Sem sucesso no pedido, "foram ter com Temístocles, a quem pagaram um suborno de 30 talentos, a troco da promessa de que a frota permaneceria no local arriscando uma batalha em defesa da Eubeia" (HERÓDOTO, VIII, 4-5), algo que Temístocles conseguiu, pagando cinco talentos a Euribíades e 
três talentos de prata a Adimanto, líder dos Corintos. Ambos acreditavam que o dinheiro tinha sido enviado pelos Atenienses para aquele mesmo fim. O restante dinheiro ficou com Temístocles. Versão ligeiramente diferente chega-nos de Plutarco (TEM. 7.5), que assume o pagamento a Temístocles "de uma grande quantidade de dinheiro" que, assegura citando Heródoto, "foi dado a Euribíades". Acreditamos que Plutarco tenha decidido ignorar que a maior parte do suborno ficou com Temístocles, já que a referência que usa como fonte, Heródoto, é bastante peremptório neste ponto.

Já antes muito criticado pelos seus hábitos dispendiosos, que o tornavam “ávido de dinheiro", e pela sua presunção, especialmente quando tentou rivalizar com os banquetes oferecidos por Címon, demasiados ostensivos mas que eram perdoados "pois era jovem e de boas famílias, ao passo que Temístocles ainda não era famoso e parecia que estava a tentar subir na vida sem os meios adequados", sendo mesmo acusado de ostentação, não demorou muito tempo até que os ataques vindos de fora começassem a ter eco entre os Atenienses. Além disso, e como os partidários deste estadista eram maioritariamente das classes mais desfavorecidas, eram também eles mais fáceis de ser aliciados por aristocratas adeptos do regime oligárquico. Com o tempo, as acusações contra Temístocles foram ganhando cada vez mais eco e "aqueles que temiam a eminência de que gozava, e outros que tinham inveja da sua glória esqueceram os seus serviços ao Estado, começando a exortar à diminuição do seu poder e ao rebaixamento da sua presunção" (DIO. IV. 54.5). 
O forte desejo de afirmação pessoal e vaidade de Temístocles, sempre afirmado pelas fontes, também o parecem ter tornado um alvo mais fácil para a propaganda, ainda para mais quando contra si tinha Címon, cuja influência estava em crescendo. "Quando ele [Címon] enveredou pela politica as pessoas receberam-no de braços abertos, promovendo-o, já que estavam completamente saturadas de Temístocles, às maiores honras e cargos da cidade" (PLUT. CIMON, 5.4); isto apesar de Címon ser de tal forma pro-Esparta que até terá dado o nome de Lacedemónio a um dos seus filhos.

As acusações de corrupção e de apoio aos Persas contra Temístocles foram então ganhando eco, obrigando-o por diversas vezes a lembrar aos Atenienses todos os seus feitos quando tomava a palavra na Assembleia, até que ele próprio se cansou de se defender. "Por que vos cansais de ser beneficiado tantas vezes pelo mesmo homem?" (PLUT. TEM. 22.1), chegou a questionar. Por fim, e quanto mais insistia nos seus feitos para sua defesa, acabando mesmo por assumir ter recebido cartas do espartano Pausânias (DIO. IV. 55.8) onde este insistia com ele para se juntar aos Persas, mais odioso se ia tornando aos olhos dos seus cidadãos, chegando mesmo a ofender todos os cidadãos quando avançou com a construção de um templo à deusa Ártemis perto de sua casa, a que chamou Melhor Conselheiro, deixando implícito que tinha sido ele, Temístocles, o melhor conselheiro da cidade e dos Gregos. Perto do templo foi ainda erguida uma estátua do próprio Temístocles. 
Os rumores, receios e a inveja perante o estatuto de Temístocles chegam neste ponto ao seu auge, com os cidadãos atenienses a acabarem por condená-lo ao ostracismo como forma de reduzir o seu poder, prestígio e influência na polis, como era aliás o objectivo teórico da Lei do Ostracismo: evitar o poder desmesurado. O alívio da inveja sentida pelos cidadãos perante Temístocles, que assim forçavam a humildade aos eminentes, é também um motivo apontado por Plutarco para a condenação que o estadista ateniense acabou por sofrer - podemos atribuí-la, pois, à má fama que o político sempre acarretou consigo, por própria culpa, e também à influência crescente de Címon e da intervenção de Esparta nos assuntos internos de Atenas, nomeadamente ao arrastar o nome de Temístocles repetidamente na lama.

Em resultado do ostracismo de Temístocles, Címon fica com o caminho totalmente aberto para dominar a política da polis nos anos seguintes, algo que "os Atenienses inicialmente gostaram, até porque não vislumbravam vantagens para Esparta do favorecimento que the davam" (PLUT. CIM. 16.2). Címon foi Estratego entre 476 e 463 a. C., período em que aproveitou para conter a democratização da polis, especialmente através da criação das clerúquias, ou colónias, onde oferecia terras aos cidadãos mais pobres, afastando-os do centro de decisão de Atenas. Manteve também a sua política de aproximação a Esparta que, ironicamente, seria a razão da sua posterior queda em desgraça.

O último ano de que há registos de Temístocles em Atenas é na Primavera de 476 a. C., "Adimantus era Arconte" (TEM. 5.4), quando 
foi corego, espécie de mecenas, de Frínico, poeta vencedor das Dionísas daquele ano - o ostracismo do estadista deve ter ocorrido pouco depois. Mesmo após a saída forçada de Atenas, Temístocles prosseguiu no seu esforço contra a ameaça de Esparta desde Argos, mantendo-se em contactos com os rivais daquela polis militar - terá procurado edificar uma aliança contra os Espartanos, mais uma vez antecipando as tensões futuras que iriam assolar a sua Atenas. Esta persistência, porém, levou Esparta a desferir o golpe final no Ateniense, ao conseguir finalmente associá-lo à traição de Pausânias.

\section{Morte de Temístocles}

A queda em desgraça de Temístocles ocorre no período entre a segunda guerra persa e o início da guerra que dividiu a Liga do Peloponeso e a Liga de Delos, marcado pelo fim da aliança Grega que permitiu empurrar os Persas para fora do Continente, e mais tarde também de todo o Egeu. Este foi um período muito conturbado em termos de política interna grega, com a aliança pan-helénica a cair, e com Esparta e Atenas, líderes da liga do Peloponeso e da recém-criada liga de Delos, respectivamente, a tentarem quebrar a liga da polis rival.

Entre as exigências crescentes que cada uma das poleis foi apresentando à outra, Esparta fez valer-se da morte de Pausânias, e das cartas com ele encontradas, para dar a estocada final no percurso de Temístocles na Grécia, acusando-o de participar na traição de Pausânias, algo que nenhum autor corrobora. Plutarco (TEM. 23.2), que recusa as acusações feitas a Temístocles, assume que este recebeu um convite de 
Pausânias para se juntar à sua causa. "Temístocles rejeitou com firmeza a solicitação, declarando-lhe abertamente que não queria ter com ele nenhuma participação nesse assunto." As cartas encontradas com Pausânias depois da sua morte, porém, escritas por Temístocles, foram suficientes para a acusação vingar, com o Estadista a ver-se condenado in absentia pelos seus Atenienses.

Temístocles, obrigado a fugir da Grécia, viu-se então forçado a oferecer os seus serviços aos Persas, já que dada a sua personalidade jamais seria capaz de optar por uma reforma tranquila, sendo recebido de braços abertos depois de em troca oferecer ajuda num futuro ataque à Grécia. Nomeado governador de Magnésia em 465 a. C., acabou por ser confrontado com o crescente aumento do poder marítimo de Atenas nos anos seguintes, que levou Artaxerxes, rei persa, a convocar Temístocles para organizar a defensiva persa contra os gregos. Segundo Plutarco, foi nesta altura que o Ateniense tomou a decisão de terminar a própria vida por se julgar incapaz de cumprir o que tinha prometido, corria "o sexagésimo-quinto ano da sua vida", estávamos em 459 a. C. "Dizem que o Rei, ao lhe contarem a causa e a razão da sua morte, admirou o homem ainda mais, continuando a tratar os seus amigos e parentes com bondade.” (TEM. 31.5)

\section{Fontes}

ARISTÓTELES, Constituição dos Atenienses, Delfim Ferreira Leão (tradução), Lisboa, Gulbenkian, 2011. 
ARISTÓTELES, Política, Livro III, versão inglesa traduzida por Benjamin Jowett, exemplar policopiado disponível em: www.constitution.org/ari/polit_00.htm.

DIODORO, Livro IV, publicado no vol. II da Loeb Classical Library, 1935, exemplar policopiado disponível em: http://penelope.uchicago.edu/Thayer/E/Roman/Texts/Diodorus_Siculus/ $4 \mathrm{~A}^{*} \cdot \mathrm{html}$.

DIODORO, Livro XI, publicado no vol. IV da Loeb Classical Library, 1946, exemplar policopiado disponível em: http://penelope.uchicago.edu/Thayer/E/Roman/Texts/Diodorus_Siculus/ $11 \mathrm{~A}^{*} \cdot \mathrm{html}$.

HERÓDOTO, Livro VI, José Ribeiro Ferreira e Delfim Leão (tradução), Lisboa, Edições 70, 2000.

HERÓDOTO, Livro VIII, José Ribeiro Ferreira e Carmen Leal Soares (tradução), Lisboa, Edições 70, s.d.

HERÓDOTO, Livro VII versão inglesa traduzida por George Rawlinson, editada por Bruce J. Butterfield, Modern Library, 1942. Exemplar policopiado disponível em: http://tinyurl.com/lzdmhgn.

HERÓDOTO, Livro IX versão inglesa traduzida por George Rawlinson, editada por Bruce J. Butterfield, Modern Library, 1942. Exemplar policopiado disponível em: http://tinyurl.com/oenoocd.

PLUTARCO, Vidas Paralelas: A Vida de Temístocles, publicado no vol. II da Loeb Classical Library, 1914, exemplar policopiado disponível em: http://tinyurl.com/2kt8xh.

PLUTARCO, Vidas Paralelas: A Vida de Nícias, publicado no vol. III da Loeb Classical Library, 1916, exemplar policopiado disponível em: http://tinyurl.com/2416cf.

PLUTARCO, Vidas Paralelas: A Vida de Aristides, publicado no vol. IV da Loeb Classical Library, 1916, exemplar policopiado disponível em: http://tinyurl.com/24lbtp. 
PLUTARCO, Vidas Paralelas: A Vida de Címon, publicado no vol. II da Loeb Classical Library, 1914, exemplar policopiado disponível em: http://tinyurl.com/29ougb

TUCIDÍDES, História da Guerra do Peloponeso, David Martelo (tradução), Lisboa, Edições Sílabo, 2008.

\section{Bibliografia}

Cambridge Ancient History, vol IV, editado por John Boardman, N. G. L. Hammond, D. M. Lewis, e M. Ostwald, Cambridge University Press, 1988.

RIBEIRO FERREIRA, José e FERREIRA LEÃO, Delfim, Dez Grandes Estadistas Atenienses, $1^{a}$ edição, Lisboa, Edições 70, 2010.

RAUBITSCHEK, Antony E., The Origin of Ostracism, American Journal of Archaeology, vol. 55, n⿳3 , editado pelo Archaelogical Institute of America, 1951, exemplar disponível em: http://www.jstor.org/stable/500970.

FROST, Frank J., Themistocles and Mnesiphilus, publicado em "Historia: Zeitschrift für Alte Geschichte", Bd. 20, 1971, pp 20-25, exemplar policopiado disponível em: http://www.jstor.org/stable/4435177.

Recebido em: 10/05/2014 Aceito em: 05/12/2014 